\title{
PEMBINAAN PEGAWAI DALAM RANGKA PENINGKATAN KINERJA APARATUR DI BAGIAN KEUANGAN SEKRETARIAT DAERAH KABUPATEN PINRANG
}

\section{PERFORMANCE IMPROVEMENT OF EMPLOYEES IN THE FINANCLAL SECTION OF THE REGIONAL SECRETARIAT PINRANG DISTRICT}

\begin{abstract}
Sitti Arifah ${ }^{1}$
Universitas

Sawerigading

Makassar ${ }^{1}$

email:arifah.sitti1960@

gmail.com

IJI Publication

p-ISSN: 2774-1907

e-ISSN: 2774-1915

Vol. 1, No. 2, pp. 131-

136, Maret 2021

\footnotetext{
Unit Publikasi Ilmiah Intelektual Madani Indonesia
}

Abstrak: Penelitian ini bertujuan untuk mengetahui upaya pembinaan pegawai dalam rangka peningkatan kinerja aparatur dan hasil-hasil pelaksanaan pembinaan dan peningkatan kinerja aparatur pada Bagian Keuangan Sekretariat Daerah Kabupaten Pinrang. Penelitian ini menggunakan metode kuantitatif. Teknik pengumpulan data yang digunakan adalah observasi, wawacara, kuesioner. Hasil penelitian dianalisis dengan analisis kuantitatif dalam bentuk analisis frekuensi tabel distribusi dan presentase. Hasil penelitian menunjukkan bahwa upaya pembinaan pegawai di Bagian Keuangan Sekwilda Pinrang telah dilaksanakan dengan berpedoman pada peraturan perundang-undangan yang berlaku UU. Nomor 43 Tahun 1999. Pembinaan pegawai melalui pendidikan dan latihan antara lain berupa; Diklat Struktural (Diklatpim) dan Diklat Teknis fungsional. Diklat Kepemimpinan/penjenjangan masih dirasakan cukup kurang diikuti oleh pegawai. Sedangkan Diklat teknis, Fungsional telah cukup memadai, dimana secara keseluruhan pegawai telah mengikuti Diklat Teknis fungsional, bahkan terdapat beberapa orang pegawai yang pernah mengikuti beberapa jenis Diklat teknis dan fungsional. Hasil pembinaan dan pengembangan pegawai yang telah dilakukan tersebut, ternyata menunjukkan bahwa seluruh jabatan struktural yang ada tersebut telah diisi oleh pegawai dengan persyaratan kompetensi yang ada.

Kata Kunci: Pembinaan Karier, Peningkatan Kerja, Pegawai Negeri Sipil.

Abstract: This study aims to determine the efforts of employee development in order to improve the performance of the apparatus and the results of the implementation of coaching and improving the performance of the apparatus in the Finance Section of the Regional Secretariat of Pinrang Regency. This study uses quantitative methods. Data collection techniques used are observation, interviews, and questionnaires. The results of the study were analyzed by quantitative analysis in the form of frequency analysis of distribution tables and percentages. The results of the study indicate that efforts to develop employees in the Finance Section of the Regional Secretariat of Pinrang have been carried out by referring to the applicable laws and regulations. Number 43 of 1999. Employee development through education and training includes, among others; Structural Education and Training (Diklatpim) and functional Technical Training. Leadership training/leveling is still felt to be quite less followed by employees. Meanwhile, the technical and functional education and training are adequate, where all employees have attended functional technical training, and there are even some employees who have attended several types of technical and functional training. The results of the training and development of employees that have been carried out have shown that all existing structural positions have been filled by employees with the existing competency requirements.

Keywords: Career Development, Job Improvement, Civil Servants.

\section{PENDAHULUAN}

Eksistensi sumber daya manusia aparatur yang profesional sangat dibutuhkan dalam penyelenggaraan tugas umum pemerintahan dan pembangunan. Dengan masih terdapatnya isu-isu pelayanan yang tidak sesuai dengan standar prosedur pelayanan, seperti pelayanan yang berbelitbelit, adanya pungutan liar, pilih kasih (nepotisme) serta perilaku aparat yang selalu menunda-nunda pekerjaan, seperti seharusnya diselesaikan satu hari saja akan tetapi memakan waktu berhari-hari, dan lainlain sebagainya.

Undang-undang Nomor 43 tahun 1999 Tentang Pokok-Pokok Kepegawaian merupakan landasan yang yuridis formal dalam kerangka pelaksanaan pembinaan dan pemberdayaan aparatur yang harus dilaksanakan secara konsekuen dan konsisten. Hal ini berarti bahwa pola peningkatan kualitas sumber daya manusia bagi aparatur negara selalu mengacu pada proses peningkatan profesional dan 
pembinaan bakat pegawai sehingga dapat mencerminkan jiwa pengabdian pada tugas dan jabatan secara lebih akurat dengan pelayanan yang lebih memuaskan.

Pada kenyataannya upaya pembinaan dan pemberdayaan aparatur didaerah seringkali kurang obyektif, terutama masih adanya "nepotisme" dalam hal pangkat dan jabatan dan kesempatan untuk pengembangan karier yang lebih memadai, bahkan distribusi pendapatan diluar gaji (insentif) belum merata, sehingga menciptakan ketidakpuasan di lingkungan kerjanya, sehingga terdapat segelintir individu aparatur yang mengambil kesempatan untuk mendapatkan pendapatan diluar ketentuan tugasnya (korupsi) sehingga merugikan pelayanan umum secara keseluruhan. Oleh sebab itu dalam rangka pembinaan pegawai dalam peningkatan kualitas kinerja aparatur komitmen terhadap peningkatan pendidikan dan latihan, moril kerja, pengalaman serta peningkatan motivasi kerja dengan memberikan kesempatan yang sama untuk memperoleh pemenuhan kebutuhan pada berbagai tingkatan.

Saat ini kenyataan menunjukan bahwa kemampuan kinerja aparatur semakin dibutuhkan, mengingat arus informasi yang sudah mengglobal. Dimana tuntutan era persaingan sumber daya manusia semakin tidak dapat dielakkan lagi. Oleh karena itu, perlu kiranya dilakukan upaya persiapanpersiapan dalam menyongsong era persaingan akan kualitas sumber daya manusia (SDM) yang benar-benar profesional, dalam hal ini adanya programprogram pengembangan kinerja aparatur ke arah peningkatan kualitas dengan memperhatikan aspek kemampuan (skill dan kecakapan) dalam menjawab tantangan perkembangan globalisasi terutama terhadap aparat pengelola keuangan daerah.

Manusia merupakan unsur sentral dalam hampir semua kegiatan organisasi. Peralatan-peralatan moderen dengan teknologi canggih tidak akan banyak bermanfaat apabila manusia yang mengelolanya tidak mampu untuk mengoperasikannya. Oleh sebab itu setiap individu yang menjadi pekerja dalam suatu organisasi, seperti halnya pegawai negeri sipil dalam lingkup Bagian Keuangan Kantor Bupati Pinrang perlu dibekali dan ditingkatkan keterampilan dan pengetahuannya terhadap aspek-aspek pekerjaannya, baik aspek teknis maupun aspek administrasi umum.

Pembinaan pegawai negeri sipil dimaksudkan untuk meningkatkan bobot dan kualitas pelaksanaan tugas pekerjaannya, serta kemampuan untuk mengembangkan tugas-tugas jabatannya baik jabatan fungsional maupun struktural.

Sistem pembinaan karier seringkali dikaitkan pula dengan klasifikasi pendidikan, latihan jabatan dari si pegawai, karena pendidikan atau latihan tersebut dianggap pula suatu peningkatan dalam kemampuan. Oleh karena itu pula maka untuk membina karier pegawai pada tingkat-tingkat tertentu kadang-kadang diperlukan suatu ujian atau test. pelaksanaan pembinaan karier bagi pegawai negeri sipil adalah merupakan suatu kebutuhan yang perlu disempurnakan secara terus menerus, agar pelaksanaannya dapat menjamin adanya kesinambunngan pembinaan karier ke depan.

Makna yang lebih penting dipahami dalam melihat keterkaitan ataupun pengaruh pelaksanaan pembinaan karier pegawai negeri sipil terhadap pelaksanaan tugas-tugas rutin dilingkungan kerja tertentu, adalah bahwa diharapkan profesionalisme akan meningkat melalui upaya-upaya peningkatan peran dan fungsi dalam pelaksanaan tugas-tugas, sehingga pelaksanaan seluruh tugas-tugasnya dapat lebih lancar dan lebih berkualitas. Dengan demikian seluruh tugas rutin yang tercermin dalam kerangka tugas aparatur dapat dilaksanakan secara profesional melalui peningkatan kualitas aparatur. 
Pada tingkat daerah, khususnya pada Bagian Keuangan Sekretariat Daerah Kabupaten Pinrang berbagai variabel dapat diasumsikan sebagai pokok permasalahan dalam proses pengkajian terhadap pembinaan pegawai selaku aparatur pemerintahan yang diiringi dengan peningkatan jabatan, peran dan tanggung jawab dalam pelaksanaan tugasnya.

Pada kenyataanya upaya pembinaan aparatur di Bagian Keuangan Kantor Bupati Pinrang, dalam hal ini Sekretariat Wilayah daerah, masih berlangsung agak kurang obyektif dan kurang transparan, dimana sistem pembinaan meliputi promosi, pendidikan dan latihan dalam jabatan masih sering kali terdapat pengaruh dari hubungan timbal balik dari kedekatan sebagai keluarga, teman ataupun karena suka atu tidak suka (nepotisme) terhadap individu-individu yang memperoleh peluang mendapatkan promosi, sehingga pihak lain yang memiliki pengalaman dan prestasi kerja yang memadai menjadi dikesampingkan dalam proses pelaksanaan pembinaan tersebut.

Pelaksanaan pembinaan karier pegawai yang baik, tentu saja harus bersandar pada peraturan perundang-undangan yang berlaku, yaitu Undang-Undang Nomor 43 tahun 1999 dan Peraturan Pemerintah Nomor 96 tahun 2000 tentang Wewenang Pengangkatan, Pemindahan, dan Pemberhentian Pegawai Negeri Sipil serta Peraturan Pemerintah Nomor 99 yang telah diubah dengan Peraturan Pemerintah Nomor 12 tahun 2002 tentang Kenaikan Pangkat Pegawai Negeri Sipil serta Peraturan Pemerintah Nomor 100 tentang Pengangkatan Pegawai Negeri Sipil Dalam Jabatan Struktural. Dalam peraturan perundang-undangan tersebut jelas dikehendaki pembinaan dan pengembangan kepegawaian dengan mengacu pada prinsip sistem karier dan prestasi kerja, yaitu hanya orang-orang yang berpengalaman dan berprestasi kerja yang tinggi diberikan prioritas untuk menduduki jabatan-jabatan yang tersedia, terutama jabatan-jabatan tingkat tinggi yang memerlukan kemampuan teknis administratif, profesional dan memiliki loyalitas, impersonality serta integritas pribadi terhadap seluruh aspek tugastugasnya.

\section{METODE}

Penelitian ini menggunakan metode kuantitatif. Populasi dalam penelitian ini adalah seluruh Pegawai Negeri Sipil yang ada di Bagian Keuangan Kantor sekretariat kantor Bupati Pinrang yang berjumlah 22 orang dengan sampel penelitian menggunakan sampel jenuh, yaitu mengambil seluruh populasi sebagai penelitian. Teknik pengumpulan data yang digunakan adalah observasi, wawacara, kuesioner. Hasil penelitian dianalisis dengan analisis kuantitatif dalam bentuk analisis frekuensi tabel distribusi dan presentase.

\section{HASIL DAN DISKUSI}

Sekretariat Wilayah/daerah Kabupaten mempunyai tugas membantu Bupati Kepala Daerah dalam melaksanakan Tugas pokok penyelenggaraan pemerintahan, administrasi, organisasi dan tatalaksana serta memberikan pelayanan administratif kepada seluruh perangkat daerah. Untuk penyelenggaraan tugas pokok tersebut di atas maka sekretariat wilayah/daerah kabupaten mempunyai fungsi, a) Pengkoordinasian perumusan kebijaksanaan pemerintah daerah, b) Penyelenggaraan administrasi pemerintahan, c) Pengelolaan sumber daya aparatur, keuangan, prasarana dan sarana pemerintahan daerah, d) Pelaksanaan tugas lain yang diberikan oleh bupati sesuai dengan tugas dan fungsinya.

Khusus pada bagian keuangan Sekwilda Kabupaten Pinrang, maka memiliki bagian tugas keuangan, mempunyai tugas melaksanakan dan mengkoordinasikan penyusunan program, pedoman dan petunjuk teknis penyusunan dan perubahan Anggaran 
Pendapatan dan Belanja Daerah, menyelenggarakan verifikasi, perbendaharaan dan mengelola perhitungan anggaran, serta membina administrasi keuangan. Untuk menyelenggarakan tugas sebagaimana yang dimaksud, bagian keuangan mempunyai fungsi, a) Perumusan dan penyiapan kebijakan pelaksanaan penyusunan dan perubahan Anggaran Pendapatan dan Belanja Daerah, b) Perumusan dan penyiapan kebijakan penyelenggaraan verifikasi, c) Perumusan dan penyiapan kebijakan penyelenggaraan perbendaharaan,

Perumusan dan penyiapan kebijakan pelaksanaan perhitungananggaran,

Pengkoordinasian penyusunan rencana dan perubahan anggaran penerimaan dan pengeluaran, verifikasi, perbendaharaan, dan perhitungan anggaran. Bagian keuangan terdiri dari, a) Sub bagian anggaran, b) Sub bagian pembukuan, c) Sub bagian perbendaharaan.

Pilihan sebagai pegawai negeri sipil adalah berarti karier selam hidup, dalam arti hampir seluruh aktivitas dan kegiatan seharihari yang berkaitan dengan pekerjaan dicurahkan pada karier selaku pegawai negeri sipil. Seperti diketahui bahwa yang dimaksud dengan pengembangan pegawai adalah kegiatan yang dikaitkan dengan peningkatan kecakapan pegawai guna pertumguhannya yang berkesinambungan dalam organisasi serta kesiapan dalam menghadapi tugas dan tanggung jawab yang lebih luas. Dengan kegiatan pengembangan pegawai, maka sudah barang tentu diharapkan terdapat tenaga pegawai tingkat tinggi yang memiliki pengalaman dan kecakapan yang luas terhadap pekerjaan yang dihadapinya.

Menyadari sepenuhnya bahwa jabatan pegawai negeri adalah merupakan karier selama hidup, maka tidak ada pilihan kecualimemberikan kontribusi yang lebih besar kepada upaya-upaya peningkatan karier yang lebih baik lagi. Hal ini tentu didasari pada manfaat bagi diri individu pegawai itu sendiri dan organisasi tempat pegawai bekerja.

Ditengah-tengah persaingan dan kemajuan tehnologi yang semakin canggih, maka semakin dituntut kemampuan pegawai negeri untuk menguasai bidang tugasnya masing-masing, hal ini tentu menuntut adanya pembinaan dan pengembangan terutama dalam perluasan kecakapan dan keterampilan yang dirasa makin urgensif.

Menyadari pentingnya pembinaan pegawai kearah peningkatan mutu dan produktivitas kerja, maka Bagian Keungan Sekwilda Pinrang mengupayakan adanya peningkatan dan pengembangan bidang kepegawaian secara terus menerus dan menyesuaiakan dengan kebijaksanaan pengembangan karier pegawai di lingkungan pemerintah daerah Kabupaten Pinrang, sebagai salah satu organisasi birokrasi pemerintah, maka kegiatan yang paling nyata dan menonjol adalah pelaksanaan pendidikan dalam latihan bagi pegawai negeri sipil.

Pendidikan dan latihan bagi pegawai adalah merupakan suatu upaya untuk lebih meningkatkan mutu, kemapuan dan kecapakan pegawai itu sendiri, hal ini dimaksudkan agar setiap pegawai mwmiliki kesanggupan dan prestasi yang lebih baik dalam melaksanakan tugas-tugasnya yang menjadi tanggung jawabnya.

Kebijaksanaan pengembangan pegawai melalui pendidikan dan latihan adalah bertolak pada Undang-Undang No. 43 Tahun 1999 Tentang Perubahan Undang-Undang No. 8 Tahun 1974 Tentang Pokok-Pokok Kepegawaian dan Peraturan Pemerintah No. 101 Tentang Pendidikan dan Pelatihan Jabatan Pegawai Negeri Sipil.

Pemerintah Kabupaten Pinrang dalam meningkatkan kompetensi pegawai negeri sipil dengan melakukan pembinan karier. Pembinaan karier yang dilakukan terhadap pegawai negeri sipil adalah diklat penjenjangan/kepemimpinan dan diklat teknis fungsional. 
Diklat penjenjangan/kepemimpinan adalah suatu diklat yang pada dasarnya yang diperuntukkan bagi upaya mengisi struktur organisasi yang ada dilingkup tugas Bagian Keuangan Sekwilda Kabupaten Pinrang. Oleh sebab itu proses menentukan pegawai untuk ditunjuk mengikuti Diklat penjenjangan/kepemimpinan adalah cukup ketat dengan pertimbangan-pertimbangan yang agak sulit, apalagi melihat jenis dan jumlah pegawai denga klasifikasi pendidikan serta kepangkatan yang cukup kompetitif. Sehingga untuk kegiatan Diklat penjenjangan (kepemimpinan) ini menimbulkan persaingan diantara pegawai.

Selain diklat penjenjangan (kepemimpinan), juga dilakukan diklat teknis fungsional dalam rangka meningkatkan pengetahuan dan keterampilan teknis fungsional yang merupakan bagian terpenting dalam pelaksanaan tugas di bidang pengelolaan keuangan daerah, seperti diklat bendaharawan, verifikasi, pembukuan dan lain-lain sebagainya. Hasil penelitian yang telah dilakukan menunjukkan bahwa seluruh pegawai yang ada yang berjumlah 22 orang pada bagian keuangan seluruhnya telah mengikuti Diklat teknis fungsional, bahkan beberapa diantranya telah mengikuti lebih dari 8 jenis diklat teknis fungsional.

Berdasarkan penelitian yang telah dilakukan menunjukkan keseluruhan Diklat yang ada diselenggarakan di dalam Negeri, bahkan umumnya dalam lingkup Sulawesi selatan. Dan Diklat Teknis Fungsional adalah diperuntukkan bagi upaya pelaksanaan secara teknis fungsional dari berbagai kegiatankegiatan pengelolaan keuangan pada Bagian Keuangan Sekretariat Daerah Kabupaten Pinrang.

Dengan dengan adanya upaya-upaya pembinaan dan pengembangan pegawai melalui pendidikan dan latihan dan pembinaan karier berdasarkan Peraturan perundang-undangan yang ada, maka nampak bahwa hasilnya seluruh pegawai yang menduduki jabatan eselon adalah sesuai dengan kompetensinya. Namun, upaya pembinaan pegawai melalui pendidikan dan latihan pada dasarnya belum secara optimal dilakukan terutama dalam rangka Diklat Penjenjangan yang dipersiapkan untuk jabatan-jabatan struktural yang telah disusun berdasarkan struktur organisasi yang ada.

\section{KESIMPULAN}

Upaya pembinaan pegawai di Bagian Keuangan Sekwilda Pinrang ternyata telah dilaksanakan dengan berpedoman pada peraturan perundang-undangan yang berlaku UU. Nomor 43 Tahun 1999. Pembinaan pegawai melalui pendidikan dan latihan antara lain berupa; Diklat Struktural (Diklatpim) dan Diklat Teknis fungsional. Diklat Kepemimpinan/penjenjangan masih dirasakan cukup kurang diikuti oleh pegawai. Sedangkan Diklat teknis, Fungsional telah cukup memadai, dimana secara keseluruhan pegawai telah mengikuti Diklat Teknis fungsional, bahkan terdapat beberapa orang pegawai yang pernah mengikuti beberapa jenis Diklat teknis dan fungsional. Para pegawai menilai bahwa pelaksanaan Diklat Kepemimpinan/penjenjangan berlangsung dengan biasa-biasa, dalam arti siapapun yang ditunjuk untuk mengikuti pendidikan dan latihan kepemimpinan tidak menjadi masalah sepanjang telah memenuhi syarat untuk itu. Meskipun demikian terdapat persepsi pegawai yang menilai bahwa prosedur pendidikan Kepemimpinan dan Penjenjangan berjalan agak berbelit-belit, dalam cukup banyak persyaratan yang harus dipenuhi oleh seorang pegawai. Dan umumnya pegawai menilai bahwa pelaksanaan Diklat baik penjenjangan maupun teknis fungsional adalah sangat bermanfaat bagi pelaksanaan tugas pokok Bagian keuangan Sekwilda Kabupaten Pinrang. Hasil pembinaan dan pengembangan pegawai yang telah dilakukan tersebut, ternyata menunjukkan bahwa seluruh jabatan struktural yang ada tersebut 
telah diisi oleh pegawai dengan persyaratan kompetensi yang ada, hal ini diakui sebagai hasil dari pembinaan karier pegawai.

\section{REFERENSI}

Bintoro Tjokroamijojo. (1986). Pengantar administrasi Pembangunan. Jakarta: LP3ES,

Handayaningrat, Soewarno. (1989). Pengantar Ilmu administrasi dan Manajemen, Jakarta: Gunung Agung.

Kansil, CST. (1983). Sistem Pemerintahan Indonesia. Jakarta.

Kaho, Jasep Riwu. (1988). Prospek Otonomi Daerah. Jakarta: Bulan Bintang.

Manullang, M. (1986). Pengembangan Pegawai. Jakarta: Rajawali Press.

Moekijat. (1986). Manajemen Kepegawaian, Alumni Bandung.

Moenir, AS. (1991). Pendekatan Manusiawi dan Organisasi Terhadap Pembinaan Kepegawaian. Jakarta: Gunung Agung.

Musanef. (1986). Manajemen Kepegawaian Indonesia. Jakarta: Ghalia Indonesia.

Siagian, S.P. (1980) Teknik Menumbuhkan dan Memelihara Perilaku Organisasional. Jakarta: Gunung Agung.

Susilo Martoyo. (1992) Manajemen Sumber Daya Manusia. Yogyakarta BPFE.

Sugiyono. (1998). Metode Penelitian Administrasi. Jakarta: Bandung Alfabeta.

Widodo. (1977). Kepegawaian; Ensiklopedi administrasi. Jakarta: Gunung Agung.

Wijajya, A.W. (1986) Administrasi Kepegawaian Suatu Pengantar. Jakarta: Rajawali.

The Liang Gie. (1986). Ensiklopedi Administrasi. Jakarta: PT. Gunung Agung.

Undang-undang Nomor 43 Tahun 1999, Tentang Pokok-Poko Kepegawaian, Sinar Grafika, Jakarta.

Peraturan pemerintah Nomor 99 Tahun 2000, Tentang Kenaikan Pangkat pegawai Negeri Sipil Sebagaimana Telah diubah dengan Peraturan Pemerintah Nomor 12 tahun 2002.

Peraturan Pemerintah Republik Indonesia Nomor 100 Tahun 2000, Tentang Pengangkatan Pegawai dalam Jabatan Struktural.

Peraturan Pemerintah Republik Indonesia Nomor 101, Tentang pendidikan dan Latihan Pegawai Negeri Sipil.

Keputusan Gubernur Kepala Daerah Tingkat I Sulawesi Selatan Nomor 239 tahun 1999 tentang Badan Pertimbangan Jabatan dan Kepangkatan Pemerintah Daerah Tingkat I Sulawesi Selatan. 